\title{
Efficiency of airborne pollen released by honeybee foraging on pollination in oilseed rape: a wind insect-assisted pollination*
}

\author{
Jacqueline PIERRE ${ }^{1}$, Bernard VAISSIÈRE ${ }^{2}$, Patrick VALLÉE ${ }^{3}$, Michel RENARD ${ }^{3}$ \\ ${ }^{1}$ INRA, UMR 1099, "BiO3P”, BP 35327, 35653 Le Rheu Cedex, France \\ 2 INRA, UMR 406, “Abeilles et Environnement”, Domaine Saint-Paul, Site Agroparc, 84914 Avignon Cedex 9, \\ France \\ ${ }^{3}$ INRA, UMR 118, Amélioration des Plantes et Biotechnologies Végétales, BP 35327, 35653 Le Rheu Cedex, \\ France
}

Received 9 April 2009 - Revised and accepted 8 July 2009

\begin{abstract}
Oilseed rape (Brassica napus L.) is an entomophilous crop. Its pollen is covered with sticky pollenkitt and not readily released from the anthers. We investigated the role of foraging honeybees in making this pollen airborne. To assess this, six cages were laid over male-fertile (MF) and male-sterile (MS) plants; at flowering, three cages received a honeybee colony while the others served as controls. On average, approximately $25 \%$ more pollen grains were deposited on sticky slides (covered with gauze) in cages with honeybees, compared to control cages. The fruit and seed set per not-empty pod of 5 MS plants bagged under gauze to avoid bee visits were 7 times and 3.4 times higher, respectively, in the cages with honeybees than in control cages without honeybees. These results demonstrate the role of bees in releasing airborne pollen, as well as the effectiveness of this insect-assisted wind pollination: at close range, honeybees participate to pollination without touching the female flowers.
\end{abstract}

\section{Apis mellifera / airborne pollen / pollination / Brassica napus}

\section{INTRODUCTION}

Like that of all angiosperms, the pollen of oilseed rape (Brassica napus) is coated with pollenkitt, a complex mixture of lipidic, viscous substances (Stead et al., 1979; Piffanelli et al., 1998; Pacini, 2000). Due to this pollenkit, the grains are released as clumps which stick to the anthers and are not readily dislodged, even under high wind velocity (Eisikowitch, 1981; Pierre, unpubl. data).

The role of bees (Apoidea) as pollinators effecting direct pollen transfer when visiting flowers is well established. The relative importance of their pollinating activity varies

Corresponding author:

jacqueline.pierre@rennes.inra.fr

* Manuscript editor: Stan Schneider primarily with the breeding system of the plant. In the case of open pollinated oilseed rape, the seed production in the standard malefertile (MF) plants is the combined result of self-pollination, wind pollination by neighbouring plants and pollen transfer by bees (Pierre et al., in prep.) whereas for hybrid seed production bees are essential to transfer pollen from MF to male-sterile (MS) because both type of plants are physically separated within fields and pollen transfer by wind is limited to very short distances (Mesquida and Renard, 1982; Mesquida et al., 1988; Lavigne et al., 1998; Pierre et al., in prep.). Bees could also indirectly take part in pollen dispersal and pollination by making some of the pollen on their body airborne during their flight and grooming (Free and Nuttal, 1968; Free and 
Ferguson, 1983; Morh and Jay, 1988). Indeed they could pollinate flowers without touching them. Such a mechanism has been hypothesized by several authors (Mamood and Schmidt, 1991; Vaissière et al., 1996) and its incidence has even been taken into account in models (Rademaker et al., 1997), yet it remains to be demonstrated experimentally.

The aim of our study was thus to determine whether bees could make oilseed rape pollen airborne and to determine the pollinating ability of such airborne pollen. To this end, a cage experiment, with or without bees, was conducted to measure (i) the quantity of airborne pollen released by honeybees, and (ii) the pollination efficiency of such airborne pollen.

\section{MATERIAL AND METHODS}

\subsection{Experimental layout}

The experiment was conducted in a meadow under insect-proof cages $(3 \mathrm{~m} \times 3 \mathrm{~m} \times 2 \mathrm{~m}$ high covered with netting with $1.2 \times 1.2 \mathrm{~mm}$ openings). Six cages were planted with 4 contiguous rows of male fertile (MF) plants of the oilseed rape spring cultivar 'Tanto' and 2 contiguous rows with the male sterile (MS) plants (cultivar 'Fu-Tanto') and two treatments were applied ( 3 cages with honeybees, 3 cages without honeybees). A seventh cage was sown with MS plants only and without honeybees to assess the extent of the pollination by airborne pollen that might have entered the cage while passing through the net (net control).

Two experiments were conducted in parallel: one to quantify the airborne pollen deposition on glass slides, the other to measure pollination efficacy. The foraging activity of the honeybees, the number of male flowers and climatic conditions, that are factors potentially influencing the airborne pollen production and pollination were also recorded.

\subsection{Deposition of airborne pollen}

Pollen released by honeybees was collected on four microscope glass slides coated with doublesided sticky tape. The slides were laid horizontally and located $1.1 \mathrm{~m}$ above the ground, corresponding to the average location of flowers. A piece of gauze was placed $10 \mathrm{~cm}$ above the slides, to allow comparison between pollen deposition and pollination of the bagged MS plants tested in the second experiment (see below). To minimise the risk of rain exposure, series of slides were collected after 7 periods of exposure (E1 to E7) of variable duration and under variable climatic conditions, some of which nevertheless included some rain. Because counting pollen grains is time-consuming, slides were exposed only in 4 of the cages planted with MS and MF plants (cages 1 and 2 with honey bees; cages 3 and 4 without). The number of grains deposited per unit area was recorded by counting them under a binocular microscope $(\times 500)$ over a central area $\left(1.2 \times 2.5 \mathrm{~cm}=3 \mathrm{~cm}^{2}\right)$ on each slide and on each of the 4 slides exposed in each cage ( 4 replicates/cage/period). Because the environmental conditions during the 7 periods of exposure were very different, the analysis of data was made separately for each period, using a two-way ANOVA model with "cages" nested under "treatment". Before analysis, the pollen count data were transformed (square root) and the normality was verified.

\subsection{Assessment of airborne pollen on plant pollination}

At the onset of flowering, $5 \mathrm{MF}$ and $10 \mathrm{MS}$ plants of similar size and distributed throughout the covered area were selected and tagged in each cage. The five MF and five of the MS plants were left to be open-pollinated, while the remaining five MS plants were bagged under gauze (hexagonal openings, $2 \mathrm{~mm}$ diameter) to prevent bee visits. Three of the 6 cages then received a small colony of honeybees (Apis mellifera L.), while the remaining cages were used as control without bees. Before the introduction of honeybees, open flowers were removed from the tagged plants in all cages and plant densities were equalized among the 6 cages by removing a few plants as necessary. The experiment was performed over 13 days during the main flowering period, i.e. from the onset of full-flowering of MS plants to the first main drop of petals, after which the beehives were removed. All buds remaining after the withdrawal of the beehives were removed from the tagged plants in all 6 cages, so that pollination could be assessed only on the flowers that opened during the 13 days when honeybees were present.

Pollination was measured on the bagged MS plants, using the open-pollinated MF and MS plants 
as controls. This is necessary because caging has been shown to induce lower seed yields. All tagged plants were harvested 16 days after bees were removed, enabling to assess fruit set and seed production without loosing seeds during harvest. In the cage with MS plants only (net control), excessive growth and flowering due to lack of pollination led plants to intermingle; this made it impossible to collect plants individually. Therefore, 50 main racemes chosen at random throughout this cage were harvested, one week later than in the other 6 cages to ensure ripening of the main racemes. Fruit set was calculated as the number of not-empty pods divided by the total number of pods. Seed production was determined as the number of seeds per non-empty pod. An average of 332 pods were harvested and examined per tagged plant (i.e. a total of about 1660 pods per cage), while in the cage with MS plants only, a total of 2788 pods were examined.

An overall analysis of variance of the data was made taking into account three factors (treatment, cage nested under treatment, and plant type nested under treatment and cage). Then, a separate analysis of the pollination for each plant type was conducted with a two-way analysis of variance, and a comparison of means between cages with and without honeybees (Tukey test). Before analysis, the data were transformed (respectively angular transformation of Bliss (1938) for fruit set and square root for number of seeds per pod) and the normality was verified.

\subsection{Density of available flowers and foraging honeybees}

Both factors were recorded under the 4 cages corresponding to the experiment made on the pollen deposition. The density of available MF flowers $/ \mathrm{m}^{2}$ was measured following Pierre et al. (1996) on 6 dates during the experiment. Meanwhile, the number of honeybees foraging on MF plants was registered for $3 \mathrm{~min}$, from outside the cage (not to disturb bees), when the weather conditions were propitious (no rain and temperature higher than $12{ }^{\circ} \mathrm{C}$ ). That lead to15 replicates distributed over 8 dates from full-flowering to the decrease of flowering. The measures were made quasi simultaneously on both cages (cage $1=$ colony 1 ; cage $2=$ colony 2). The foraging activity (number of foraging honeybees per 1000 flowers) was estimated from these data.

\subsection{Climatic conditions}

The duration of slide exposure and the climatic conditions during these (temperature, cumulative rain, relative humidity, cumulative wind run and maximal wind speed) were recorded.

\section{RESULTS}

\subsection{Airborne pollen}

The amount of pollen deposited was, on average over the 7 exposure periods, $26.5 \%$ higher in the cages with honeybees (cages 1 and 2 ; overall mean $=97.6$ ) compared to the control cages (cages 3 and 4; overall mean = 71.82). However, the number of pollen grain was very variable in each cage and at each period and the difference between treatments was not always statistically significant at each pe$\operatorname{riod}($ Tab. I): it reached significance level in five of the seven periods, but failed to do so in periods 1 and 6 .

Several abiotic (Tab. II) or biotic factors (Tab. III) could affect the number of pollen grain deposited on the glass slides such as the duration of exposure, the weather conditions during exposure and the density of MF flowers or the foraging activity of honeybees in each cage. However, Spearman rank correlation tests showed no clear relation between the amount of pollen deposition and environmental factors other than relative humidity and foraging activity. For instance, pollen deposition was significantly higher in cages 2,3 , and 4 when the air was dry $(\mathrm{df}=5 ; \mathrm{r}$ respectively $-0.68,0.67$ and $-0.71 ; P<0.05)$. There was a significant relationship between the foraging activity and pollen deposition in cage 1 (df $=5 ; \mathrm{r}=0.75 ; P=0.02)$, but not in cage $2(\mathrm{df}=5 ; \mathrm{r}=0.51 ; P>0.1)$ although the bee activity was twice higher in that cage (cage $1: 8.9 \pm 1.1$ foraging honeybees/1000 flowers; cage $2: 15.1 \pm 1.5)$. The interaction between environmental factors and pollen deposition was rather complex, and difficult to predict. A detailed study of the data showed that during the first exposure period (E1), the number of MF flowers was high and the weather was very dry and windy. Under such conditions, 
Table I. Quantity of airborne pollen deposited on glass slides (mean number of grains $/ \mathrm{cm}^{2} \pm \mathrm{SE}$ ) at 7 periods of exposure (from E1 to E7) in cages with and without honeybees. The $P$ values for treatment and cage effect are given from a two-way analysis of variance.

\begin{tabular}{|l|c|c|c|c|c|c|}
\hline \multirow{2}{*}{ Period } & \multicolumn{2}{|c|}{ Cage with honeybees } & \multicolumn{2}{c|}{ Cage without honeybees } & \multicolumn{2}{c|}{ ANOVA (Pvalue) } \\
\cline { 2 - 7 } & Cage 1 & Cage 2 & Cage 3 & Cage 4 & $\begin{array}{c}\text { Treatment } \\
\text { effect }\end{array}$ & $\begin{array}{c}\text { Cage } \\
\text { effect }\end{array}$ \\
\hline E1 & $148.30 \pm 55$ & $496.00 \pm 133$ & $236.10 \pm 78.5$ & $517.23 \pm 123$ & 0.477 & 0.017 \\
\hline E2 & $77.20 \pm 29.8$ & $141.70 \pm 33.5$ & $13.25 \pm 2.79$ & $27.30 \pm 15.8$ & 0.001 & 0.199 \\
\hline E3 & $29.00 \pm 8.30$ & $67.00 \pm 19.4$ & $17.67 \pm 9.07$ & $11.58 \pm 2.95$ & 0.005 & 0.115 \\
\hline E4 & $9.83 \pm 0.35$ & $46.5 \pm 21.30$ & $4.17 \pm 0.91$ & $6.83 \pm 1.69$ & 0.005 & 0.024 \\
\hline E5 & $48.30 \pm 12.90$ & $51.67 \pm 4.61$ & $30.33 \pm 4.80$ & $33.17 \pm 5.21$ & 0.039 & 0.822 \\
\hline E6 & $35.42 \pm 3.83$ & $83.00 \pm 37.5$ & $34.67 \pm 2.29$ & $25.42 \pm 3.93$ & 0.084 & 0.164 \\
\hline E7 & $30.50 \pm 4.84$ & $103.10 \pm 30.10$ & $22.83 \pm 4.99$ & $25.17 \pm 7.41$ & 0.005 & 0.011 \\
\hline
\end{tabular}

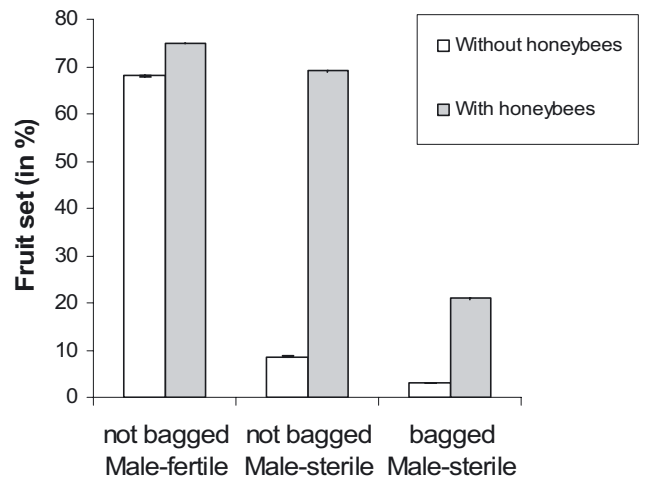

Figure 1. Percentage of Fruit set (number of pod/number of flowers; \pm standard error) on open pollinated male-fertile or male-sterile plants and on bagged male-sterile plants under cages with or without honeybees. Letters indicate means that are different $(P<0.05)$ for each category of plants, using Tukey test.

the amount of pollen deposited on the slides was very high and there was no difference between the cages with and without honeybees (average of $322 \pm 213$ and $376 \pm 84$ pollen grains $/ \mathrm{cm}^{2}$, respectively; Tab. I). By contrast, during exposure period 6 , the climatic conditions were characterized by a low mean temperature, a factor well known to reduce the foraging activity (confirmed by our data, Tab. III): this in turn can explain the absence of difference in pollen deposition between cages with or without bees at that date.

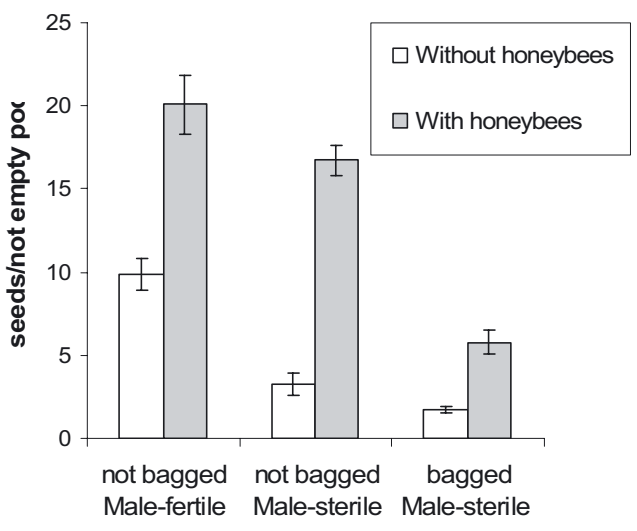

Figure 2. Number of seeds per not empty pod ( \pm standard error) on open pollinated male-fertile or male-sterile plants and on bagged male-sterile plants under cages with or without honeybees. Letters indicate means that are different $(P<0.05)$ for each category of plants, using Tukey test.

\subsection{Plant pollination}

The percentage of fruit set (Fig. 1), as well as seed set per not-empty pod (Fig. 2) was measured on the three kinds of plants (open pollinated MF and MS plants, bagged MS plants). The analysis of variance of the overall data showed effects of the three factors on fruit set (treatment: $\mathrm{df}=2, P=0.000$; cage: df $=4, P=0.064$; plant: $\mathrm{df}=12, P=0.000)$ whereas only two factors (treatment and plant) had an impact on the number of seeds per notempty pod (treatment: $\mathrm{df}=2, P=0.000$; cage: df $=4, P=0.727$; plant: $\mathrm{df}=12$, $P=0.000)$. 
Table II. Abiotic environmental conditions during the 7 periods of exposure (from E1 to E7) of the glass slides to measure pollen deposition.

\begin{tabular}{|l|c|c|c|c|c|c|}
\hline Period & $\begin{array}{c}\text { Exposure } \\
\text { duration } \\
\text { (hours) }\end{array}$ & $\begin{array}{c}\text { Mean } \\
\text { temperature } \\
\left({ }^{\circ} \mathrm{C}\right)\end{array}$ & $\begin{array}{c}\text { Total } \\
\text { precipitation } \\
(\mathrm{mm})\end{array}$ & $\begin{array}{c}\text { Relative } \\
\text { humidity }(\%)\end{array}$ & $\begin{array}{c}\text { Cumulative } \\
\text { wind } \\
(\mathrm{km})\end{array}$ & $\begin{array}{c}\text { Maximal } \\
\text { wind speed } \\
(\mathrm{m} / \mathrm{s})\end{array}$ \\
\hline E1 & 29.50 & 19.5 & 0.00 & 44 & 344 & 12 \\
\hline E2 & 24.00 & 19.8 & 0.00 & 70 & 85 & 6 \\
\hline E3 & 4.75 & 20.2 & 0.17 & 59 & 20 & 6 \\
\hline E4 & 7.50 & 22.5 & 0.00 & 60 & 31 & 4 \\
\hline E5 & 31.00 & 18.2 & 1.50 & 76 & 169 & 10 \\
\hline E6 & 42.00 & 16.6 & 0.50 & 82 & 161 & 10 \\
\hline E7 & 49.00 & 17.4 & 25.00 & 82 & 407 & 10 \\
\hline
\end{tabular}

Table III. Biotic environmental conditions during the 7 periods of exposure (from E1 to E7) of the glass slides to measure pollen deposition.

\begin{tabular}{|l|c|c|c|c|c|c|}
\hline Period & \multicolumn{3}{|c|}{ Number of available MF flowers/m ${ }^{2}$} & \multicolumn{2}{c|}{$\begin{array}{c}\text { Honbees foraging/1000 } \\
\text { flowers/3 min }\end{array}$} \\
\hline & Cage 1 & Cage 2 & Cage 3 & Cage 4 & Cage 1 & Cage 2 \\
\hline E1 & 300 & 300 & 450 & 350 & 11.8 & 18.9 \\
\hline E2 & 300 & 325 & 575 & 500 & 12.0 & 15.4 \\
\hline E3 & 300 & 275 & 575 & 500 & 6.7 & 8.9 \\
\hline E4 & 300 & 300 & 450 & 500 & 7.3 & 9.2 \\
\hline E5 & 300 & 200 & 250 & 500 & 8.1 & 16.8 \\
\hline E6 & 150 & 100 & 250 & 275 & 3.7 & 3.3 \\
\hline E7 & 110 & 80 & 220 & 245 & 5.0 & 17.3 \\
\hline
\end{tabular}

Fruit set in open-pollinated MF plants was increased by the presence of honeybees in the cages (average fruit set of $75 \%$ and $68 \%$ in the cages with and without honeybees, respectively). The difference in the seed production per pod was also significant as the pods from the cages with honey bees had more than twice as many seeds (20.1 versus 9.9).

In open-pollinated MS plants, the effectiveness of honeybees for direct pollen transfer and the low efficiency of wind pollination were clearly confirmed. The fruit set and the seed content per not empty pod showed a 8 -fold $(69 \%$ versus $8.9 \%)$ and 5 -fold (16.7 versus 3.2) increase, respectively, as a result of the presence of honeybees.

Fruit set in bagged MS plants was significantly higher in the 3 cages with honeybees than in those without honeybees (average of $21 \%$ and $3 \%$, respectively). The seed production of these bagged MS plants was also significantly higher in presence of honeybees (average of $5.8 \pm 0.7$ and $1.7 \pm 0.2$ seeds/not-empty pod in the cages with and without honeybees, respectively). Furthermore, the comparison of the cages with honeybee colonies 1 and 2 indicated that the seed content per not-empty pod was less in the cage with the lower foraging activity (average of 4.3 and 8.0 seeds/notempty pod in the cages with colony 1 and 2, respectively). Fruit set and seed content per not-empty pod in the cage with MS plants only were similar to those obtained on bagged MS plants in the cages without honeybees (fruit set $=2.9 \%$ and 1.7 seeds/not-empty pod). This indicated that some pollination by the airborne pollen coming from outside the cages was possible through the net covering the cage. Interestingly, these results also suggest that the gauze used to bag the MS plants did not noticeably reduce the pollination by airborne pollen.

\section{DISCUSSION}

The aim of this work was to determine if bees contributed to the release of airborne pollen, and whether such airborne pollen could result in effective pollination. 
The first step was to evaluate the pollen deposition on glass slides as a result of both wind and honeybee foraging compared to that from wind alone. Several experimental difficulties arose in controlling the duration of slide exposure and the weather conditions during exposure, as in some cases rainfall could not be avoided. Moreover, in many situations, the glass slides had to remain exposed during the night or when honeybees did not forage, so that pollen deposition by wind alone could take place, especially when the atmosphere was dry. Such a variability in the conditions of exposure resulted in a high variability of the number of pollen grains deposited on the slides. Nevertheless, the results demonstrated that honeybee foraging generally induced a significant increase in the amount of airborne pollen. A correlation was found between the foraging activity of colony 1 and the amounts of pollen grain deposited at each period. Nevertheless no correlation was detected with colony 2 , likely because this colony was more constantly active.

The second step of our study was to evaluate the incidence on pollination of this airborne pollen released by honeybees during their flights and grooming. This was calculated as the difference between the percentage of fruit set and the number of seeds per non-empty pod in MS plants bagged and exposed to honeybees and MS plants un-bagged and not exposed to honeybees. The differences amounted to ca. $17 \%$ for fruit set and 4 for seeds/not-empty pod. These figures may be overestimated, since (i) the density of foragers was higher in our experimental conditions than those commonly recorded on winter oilseed rape in the open (Pierre et al., 2003), and (ii) the efficiency of pollination by airborne pollen was measured after 13 consecutive days of exposure to honeybees, which is more than the total duration of exposure of slides ( 187.75 hours $=7.8$ days with interruption phases).

From these results, obtained under cages that reduce wind speed (Mesquida and Renard, 1982), it is not possible to estimate the part of pollination due, in the field, to the release of pollen in the atmosphere by honeybees. Nevertheless, our results could explain why pollen grains are found in high quantities in the air over the crop (Williams, 1884), whereas the oilseed rape pollen grains are not easily disseminated by wind because they are stick together by their viscous pollenkit (Eisikowitch, 1981).

We suggest that, as they are foraging, honeybees manipulate the pollen aggregates and participate to their breaking up in smaller and consequently lighter parts. This could lead to an increase of the atmospheric pollen amount dropped onto plants. This interpretation of our results underlines that wind and insect are not only two separate additive factors but that foraging honeybees can facilitate the pollen dissemination by the wind. This pollination mode, the existence of which was discussed by Brantjes (1981) who called it "insect-assisted wind pollination" in the context of ecological considerations, is thus now established.

\section{ACKNOWLEDGEMENTS}

The authors thank Nathalie Pelotte and Marguerite Dedryver for their technical assistance. They also thank Pr. Jean-Sébastien Pierre for his valuation of the statistical analysis of the data.

Efficacité du pollen atmosphérique largué par les abeilles butineuses dans la pollinisation du colza : une pollinisation anémophile assistée par un insecte.

Apis mellifera / pollen atmosphérique / pollinisation / Brassica napus

Zusammenfassung - Die Effizienz der Windverbreitung von Ölrapspollen durch das Sammelverhalten von Honigbienen: Eine Wind und Insekten-vermittelte Form der Bestäubung. Ölraps (Brassica napus L.) ist eine entomophile Feldfrucht, deren von einem klebrigen Pollenkitt umgebenener Pollen sich nicht leicht aus den Antheren lösen lässt. Nichtsdestotrotz findet sich dieser Pollen in der Umgebung von Ölrapsfeldern in großen Mengen in der Luft. Wir untersuchten, welche Rolle Honigbienen bei der Windverbreitung dieses Pollens spielen. Dazu wurden sechs Käfige über männlich- fertilen (MF) und männlich-sterilen (MS) Pflanzen der Kultivare 'Tanto', bzw. 'Fu Tanto' angebracht. In der Blütezeit wurde in jeweils drei der Käfige ein Honigbienenvolk gestellt, während die drei anderen als Kontrolle dienten. Ein siebter Käfig 
enthielt ausschliesslich MF Pflanzen und blieb honigbienenfrei, um den Anteil an Pollen erfassen zu können, der durch Windverbreitung durch das Netz gelangen konnte (Netzkontrolle).

Parallel hierzu führten wir zwei weitere Experimente durch, eines, bei dem der Pollenniederschlag auf Glasobjektträgern bestimmt wurde, und eines zur Bestimmung der Bestäubungseffizienz. Die Sammelaktivität von Honigbienen, die Zahl männlicher Blüten und die klimatischen Faktoren, die die Windverbreitung von Pollen fördern können, wurden ebenfalls erfasst.

Unsere Ergebnisse zeigen, dass im Mittel $25 \%$ mehr Pollenkörner auf Glasobjektträgern in Käfigen mit Honigbienen $\mathrm{zu}$ finden waren als in Käfigen ohne Bienen (bei 7 Messungen zu unterschiedlichen Zeitpunkten). Für die klimatischen Bedingungen fanden wir keine statistisch absicherbare (Spearman-Rangkorrelationstest) Korrelation zur Pollenablagerung, außer zur relativen Feuchtigkeit und der Sammelaktivität. Bei zwei von sieben Untersuchungszeitpunkten fanden wir keine statistischen Unterschiede zwischen Käfigen mit und solchen ohne Bienen: (i) wenn hohe Windgeschwindigkeiten und trockene Luft der Pollenverbreitung durch Wind förderlich waren, und (ii) wenn die Sammelaktivität der Honigbienen bedingt durch niedrige Temperaturen zurückgegangen war. Der Frucht- und der Samenansatz pro nicht-leerer Hülse lag bei 5 MS Pflanzen, die zur Vermeidung des Anflugs von Honigbienen unter Gaze gehalten worden waren, in Käfigen mit Bienen um das 3,4 bis 7-fache höher als in Käfigen ohne Bienen. Außerdem lag bei niedriger Sammelaktivität der Honigbienen der Samengehalt pro nicht-leerer Hülse in den mit Gaze bedeckten MS-Pflanzen deutlich niedriger. In der Netzkontrolle war die Bestäubung überaus gering, und der Fruchtansatz und der Samengehalt pro nicht-leerer Hülse war ähnlich der Werte, die wir für die Gaze-bedeckten Pflanzen in den Käfigen ohne Bienen gefunden hatten. Diese Ergebnisse zeigen die Bedeutung der Bienen bei der Freisetzung von Pollen zur Windbestäubung, sowie die Effizienz dieser insektenunterstützten Windbestäubung: über kurze Entfernungen hinweg können Bienen demzufolge zur Bestäubung beitragen, selbst wenn sie weibliche Blüten nicht berühren.

\section{Apis mellifera / windverbreiteter Pollen / Bestäubung / Brassica napus}

\section{REFERENCES}

Bliss C.I. (1938) The transformation in percentages for use in the analysis of variance, Ohio J. Sci. 38, 912.

Brantjes N.B.M. (1981) Nectar and the pollination of bread fruit, Artocarpus altilis (Moraceae), Acta Bot. Neerl. 30, 345-352.
Eisikowitch D. (1981) Some aspects of pollination of oil-seed rape (Brassica napus L.), J. Agr. Sci. 96, 321-326.

Free J.B., Ferguson A.W. (1983) Foraging behaviour of honeybees on oilseed rape, Bee World 64, 22 24.

Free J.B., Nuttal P.M. (1968) The pollination of oilseed rape (Brassica napus) and the behaviour of bees on the crop, J. Agr. Sci. 71, 91-94.

Lavigne C., Klein E.K., Vallée P., Pierre J., Godelle B., Renard M. (1998) A pollen dispersal experiment with transgenic oilseed rape. Estimation of the average pollen dispersal of an individual plant within a field, Theor. Appl. Genet. 96, 886-896.

Mamood A.N., Schmidt J.O. (1991) Pollination and seed set in pearl millet by caged honey bees (Hymenoptera: Apidae), Bee Sci. 1, 151-154.

Mesquida J., Renard M. (1982) Étude de la dispersion du pollen par le vent et de l'importance de la pollinisation anémophile chez le colza (Brassica napus L., var. oleifera Metzger), Apidologie 13, 353-366.

Mesquida J., Renard M., Pierre J.S. (1988) Rapeseed Brassica napus L. Productivity: the effect of honeybees Apis mellifera L. and different pollination conditions in cage and field tests, Apidologie 19, 51-72.

Morh N.A., Jay S.C. (1988) Nectar and pollen collecting behaviour of honeybees on canola (Brassica campestris L. and Brassica napus L.) J. Apicult. Res. 27, 131-136.

Pacini E. (2000) From anther and pollen ripening to pollen presentation, Plant Syst. Evol. 222, 19-43.

Pierre J., Marsault D., Genesque E., Renard M., Champolivier J., Pham-Delègue M.H. (2003) Effects of herbicide tolerant transgenic oilseed rape genotypes on honeybees and other pollinating insects under field conditions, Entomol. Exp. Appl. 108, 159-168.

Pierre J., Pierre J.S., Marilleau R., Pham-Delègue M.H., Tanguy X., Renard M. (1996) Influence of the apetalous character in rape (Brassica napus) on the foraging behaviour of honeybees (Apis mellifera), Plant Breeding 115, 484-487.

Piffanelli P., Ross J.H.E., Murphy D.J. (1998) Biogenesis and function of the lipidic structures of pollen grains, Sex. Plant Reprod. 11, 65-80.

Rademaker M.C.J., De Jong T.J., Klinkhammer P.G.L. (1997) Pollen dynamics of bumble bee visitation on Echium vulgare, Funct. Ecol. 11, 554-565.

Stead A.D., Roberts I.N., Dickinson H.G. (1979) Pollen-stigma interactions in Brassica oleacera: events prior to pollen germination, Planta 146, 211-216.

Vaissière B.E., Rodet G., Cousin M., Botella L., Torre Grossa J.P. (1996) Pollination effectiveness of honey bees in a kiwifruit orchard, J. Econ. Entomol. 89, 453-461.

Williams I.H. (1984) The concentrations of air-borne pollen over a crop of oil-seed rape (Brassica napus L.), J. Agr. Sci. 103, 353-357. 